\title{
Influence of Volatile Oils on the In Vitro Growth of Phytophthora Infestans
}

\author{
Laurentiu M. PALADE ${ }^{1,2)}$, Laura MARIN ${ }^{2)}$, Carmen MANOLE*2), Alina BUTU ${ }^{2)}$ \\ ${ }^{1}$ Department of Biotechnology, University of Agronomic Sciences and Veterinary Medicine, Bucharest, \\ Romania \\ ${ }^{2}$ Department of Biotechnologies, National Institute of Research and Development for Biological \\ Sciences, Bucharest, Romania \\ ${ }^{*}$ Corresponding author, e-mail: manolecarmen2000@yahoo.com
}

Bulletin UASVM Animal Science and Biotechnologies 71(2) / 2014,

Print ISSN 1843-5262; Electronic ISSN 1843-536X

DOI:10.15835/buasvmcn-asb:10680

\begin{abstract}
Modern agriculture depends on a wide variety of synthetic fungicides, which are continually wide spreading, resulting in human and environmental pollution. These chemicals used in excessive doses can give rise to abnormal chromosomes and degeneration within the mitotic cycle. In this sense, the development of alternative strategies, based on non-chemical fungicides for late blight management, becomes imperative. Thus, the aim of this study was to find several indigenous plant species that show antifungal activity against the pathogen Phytophthora infestans.

The bio base of the experiment consisted of indigenous plant species, namely Mentha piperita L., Pinus sylvestris L., Acorus calamus L., Salvia officinalis L., and Rosmarinus officinalis L.

The plant material was subjected to the extraction method using vapor entrainment, aiming to obtain volatile oils. The in vitro testing of the antifungal activity of the extract was achieved using the Kirby-Bauer disc (d) diffusion method. The negative control was sterile distilled water and the positive control was the commercial substance Mancozeb.

The obtained results showed that the mint volatile oil had a significant antifungal effect, totally inhibiting the growth and development of the oomycete. In the case of the volatile oils extracted from the other four species, the most intense antifungal activity was achieved by calamus volatile oil.

The results revealed that the obtained volatile oils ( $100 \%$ concentration) have fungicide (mint) and fungistatic (calamus, pine buds, sage and rosemary) effect, influencing the growth as well as the development of the oomycete P. infestans.
\end{abstract}

Keywords: antifungal, late blight, volatile oils

Introduction. Late blight management has been based on fungicide application, in many areas their applications showing an increase. Due to this action, the genotypes of the pathogen become more aggressive. At the same time, two counter-balancing factors have been developed: societal pressure for reducing pesticide use, and consumption of organically grown crops, including potato and tomato (Mizubuti, 2007). Late blight caused by the oomycete Phytophthora infestans (Mont.) de Bary is the major disease causing considerable losses in tomato (Solanum lycopersicum L.) and potato (Solanum tuberosum L.) crops (Galani, 2013; Soyulu et al., 2006).
Aims and objectives. The objective of this study was to evaluate the antifungal potential of several volatile oils from indigenous plants, by observing their influence on the in vitro growth and the development of Phytophthora infestans.

Materials and methods. In the laboratory, volatile oils were obtained using a Neo Clevenger installation. There were used $100 \mathrm{~g}$ of plant material. It was subjected to drying, grinding, mixing with distilled water, and vapor entrainment for 3-4 hours. For the antifungal activity of volatile oils against $P$. infestans, the disc diffusion method was used on potato dextrose agar medium plates. A $5 \mathrm{~mm}$ disc of a 14-day-old culture was inoculated 
in the center of each Petri dish. Three sterile filter discs, $6 \mathrm{~mm}$ in diameter, made of Whatman filter paper No. 1 , containing $1 \mu \mathrm{L}$ volatile oil, were added $2 \mathrm{~cm}$ away from the central disc. The plates were incubated at $20^{\circ} \mathrm{C}$. After 14 days, the mycelia were read against negative (distillated water) and positive control (Mancozeb 10\%).

Results and discussion. The results obtained after the incubation period were processed and interpreted. The antifungal activity of plant extracts is presented in Table 1.

The results show that the tested volatile oils have antifungal activity against the Phytophtora

Tab. 1. Antifungal activity of volatile oils obtained from indigenous plants

\begin{tabular}{ccc}
\hline $\begin{array}{c}\text { No. } \\
\text { crt. }\end{array}$ & Plant & $\begin{array}{c}\text { Mycelia growth } \\
\text { (cm) }\end{array}$ \\
\hline 1 & Mentha piperita $L$. & $0.00 \pm 0.00$ \\
\hline 2 & Pinus sylvestris L. (buds) & $3.33 \pm 1.47$ \\
\hline 3 & Rosmarinus officinalis $L$. & $6.81 \pm 0.40$ \\
\hline 4 & Acorus calamus $L$. & $3.10 \pm 0.36$ \\
\hline 5 & Salvia officinalis $L$. & $6.46 \pm 0.50$ \\
\hline 6 & Control (-) & $7.08 \pm 0.05$ \\
\hline 7 & Control ( + ) & $0.00 \pm 0.00$ \\
\hline
\end{tabular}

infestans strain, inhibiting the growth of mycelia. The obtained results show that the mint volatile oil has a significant antifungal effect, totally inhibiting the growth and development of the oomycete. In the case of the volatile oils extracted from the other four species, the intensity of antifungal activity was expressed in the following order: calamus > pine buds > sage > rosemary.
Conclusion. The results revealed that the obtained volatile oils (100\% concentration) have fungicide (mint) and fungistatic (calamus, pine buds, sage and rosemary) effect, influencing the growth as well as the development of the oomycete P. infestans.

On the other hand, the study is a contribution in this research field, particularly in the case of oils from pine buds and calamus, the data from the literature about the influence they have on the pathogen of interest being scarce.

Acknowledgements. This work has been funded by the research contract PN-II-PT-PCCA $106 / 2012$.

\section{REFERENCES}

1. Mizubuti ESG, Valdir LJ, Forbes GA. (2007). Management of Late Blight with Alternative Products. Pest Technology, 1:106-116.

2. Deacon JW (2006). Fungal biology. Blackwell Publishing Ltd.

3. Galani YJH, Nguefack J, Dakole DC, Fotio D, Tigang SP, Fouelefack FR, Amvam ZPH (2013). Antifungal potential and phytochemical analysis of extracts from seven Cameroonian plants against late blight pathogen Phytophthora infestans. Int J Curr Microbiol App Sci 2: 140-154.

4. Shukla R, Singh P, Prakash B, Dubey N K (2013). Efficacy of Acorus calamus L. essential oil as a safe plant-based antioxidant, Aflatoxin $B_{1}$ suppressor and broad spectrum antimicrobial against food-infesting fungi. Int J of Food Scie \& Tech, 48: 128-135.

5. Soylu EM, Soylu S, Kurt S (2006). Antimicrobial activities of the essential oils of various plants against tomato late blight disease agent Phytophthora infestans. Mycopathologia 161: 119-128. 